Levitsky A. P., Selivanskaya I. A., Stepan V. T., Pustovoit P. I., Stepan B. T., Stepan N. A. Comparative effect of different pathogens on the condition of dysbiosis in rat kidneys. Journal of Education, Health and Sport. 2020;10(12):32-39. eISSN 2391-8306. DOI http://dx.doi.org/10.12775/JEHS.2020.10.12.003

https://apcz.umk.pl/czasopisma/index.php/JEHS/article/view/JEHS.2020.10.12.003

https://zenodo.org/record/4309934

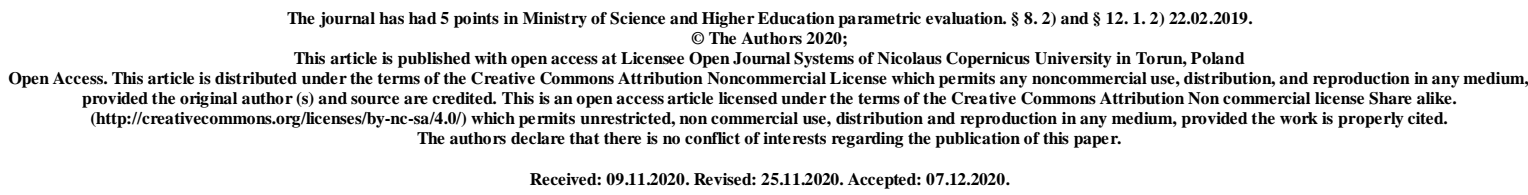

UDK 616.61:616.34:616.35:612.3:577.15

\title{
COMPARATIVE EFFECT OF DIFFERENT PATHOGENS ON THE CONDITION OF DYSBIOSIS IN RAT KIDNEYS
}

\author{
A. P. Levitsky ${ }^{1}$, I. A. Selivanskaya ${ }^{2}$, V. T. Stepan ${ }^{3}$, P. I. Pustovoit ${ }^{4}$, B. T. Stepan ${ }^{5}$, \\ N. A. $\operatorname{Stepan}^{3}$ \\ ${ }^{1}$ Odessa National Academy of Food Technologies \\ ${ }^{2}$ Odessa National Medical University \\ ${ }^{3}$ Bukovina State Medical University, Chernovtsy \\ ${ }^{4}$ Municipal Institution «Odessa Regional Clinical Hospital» \\ ${ }^{5}$ Lesya Ukrainka Volyn National University
}

\begin{abstract}
Aim. Compare the effect of different pathogens on the development of kidney dysbiosis.

Methods. The pathogens used were hydrazine sulfate, prednisolone, cyclophosphamide, lincomycin, and lipopolysaccharide (LPS). The condition of kidney dysbiosis was assessed in rats by a decrease in lysozyme activity and an increase in urease activity.

Results. A decrease in the activity of lysozyme in the kidneys under the action of pathogens was established, which, when calculated per $1 \mathrm{mg}$ of a pathogen, is hundreds of times stronger in LPS. All pathogens cause an increase in urease activity in the kidneys, which, when calculated per $1 \mathrm{mg}$ of a pathogen, is hundreds of times stronger in LPS. A
\end{abstract}


similar effect is exerted on the degree of dysbiosis, determined by the ratio of the relative activities of urease and lysozyme.

Conclusion. All pathogens (except lincomycin) cause the development of dysbiosis in the kidneys, due to the possible bacteriolysis of tissue gram-negative bacteria with the release of LPS.

Key words: kidney; pathogens; lipopolysaccharide; lysozyme; urease; dysbiosis.

\section{INTRODUCTION}

Dysbiosis is a violation of the interaction of a macroorganism with its endogenous microbiota [1]. It occurs as a result of the development of local dysbiosis (i.e., a violation of the qualitative and quantitative ratio of probiotic and conditionally pathogenic bacterial species) in a specific biotope and a decrease in the level of nonspecific antimicrobial immunity is mandatory.

The most common manifestation of dysbacteriosis is an increase in the number of opportunistic bacteria, which can be determined by seeding methods or by PCR. However, the seeding method detects less than $1 \%$ of available bacteria [2], and the PCR method is more qualitative than quantitative and also too expensive [3].

We propose to use to assess the growth of opportunistic bacteria to determine the activity of the enzyme urease, which is not formed by somatic cells, but is produced by a significant number of species of opportunistic bacteria [4].

To determine the state of nonspecific antimicrobial immunity, we propose to use the activity of the enzyme lysozyme, which not only causes lysis of a number of bacteria, but also binds the main toxin of opportunistic gram-negative bacteria - lipopolysaccharide (LPS) [5].

Various pathogens cause a decrease in the level of lysozyme in the tissues of the oral cavity, stomach, liver, mucous membrane of the colon [6]. We found a decrease in lysozyme activity in the kidneys of rats under the action of a number of pathogens $[6,7]$.

We have proposed an enzymatic method for determining organ (local) dysbiosis by the ratio of the relative activities of urease and lysozyme [8].

The aim of this work was to determine the comparative effect of different pathogens on the activity of lysozyme, urease and the degree of dysbiosis in the kidneys of rats.

\section{MATERIAL AND RESEARCH METHODS}

Hydrazine sulfate, known as a hepatotoxicant, the corticosteroid prednisolone, as an immunosuppressant, the cytostatic cyclophosphamide, the antibiotic lincomycin, and intestinal endotoxin lipopolysaccharide (LPS) were used as pathogens. 
The experiments were performed on 91 white Wistar rats, in 7 experimental series, in which half of the rats received the above pathogens. The total dose of pathogen obtained by one rat is shown in table 1 .

Table 1. Total dose of pathogens $(\mathrm{mg} / \mathrm{kg})$

\begin{tabular}{|l|c|}
\hline \multicolumn{1}{|c|}{ Pathogens } & $\begin{array}{c}\text { Total dose, } \\
\mathrm{mg} / \mathrm{kg}\end{array}$ \\
\hline Hydrazine sulfate, in / abdominal & 150 \\
\hline Prednisolone, per os & 105 \\
\hline Cyclophosphamide, in / abdominal, series I & 90 \\
\hline Cyclophosphamide, in / abdominal, series II & 90 \\
\hline Lincomycin with drinking water & 300 \\
\hline LPS in / abdominal & 0,40 \\
\hline LPS, oral applications & 0,066 \\
\hline
\end{tabular}

After the euthanasia of animals in kidney homogenates, the activity of lysozyme was determined by the bacteriolytic method using a suspension of Micrococcus lysodeikticus as a substrate [9].

Urease activity was determined by the rate of hydrolysis of urea, which was assessed by the amount of ammonia using Nessler's reagent [10].

The degree of dysbiosis was calculated by the method of A. P. Levitsky [7].

The results of the experiments were subjected to standard statistical processing [11].

\section{RESULTS AND DISCUSSION}

Table 2 presents the results of determining the activity of lysozyme in the kidneys of rats treated with various pathogens. These data show that in all cases, except for lincomycin, pathogens significantly reduce the level of lysozyme, and to the greatest extent cyclophosphamide.

But if we calculate the percentage decrease in lysozyme activity per $1 \mathrm{mg}$ of pathogen (specific anti-lysozyme activity), we obtain the results presented in Fig. 1.

It is seen that the largest decrease in lysozyme activity is caused by LPS: in comparison with the action of hydrazine sulfate 275 times more (when administered intraperitoneally) and 2518 times (after oral administration of LPS). 
Table 2. Lysozyme activity in the kidneys of rats under the action of various pathogens

\begin{tabular}{|l|c|c|c|c|}
\hline \multicolumn{1}{|c|}{ Pathogens } & \multirow{2}{*}{$\begin{array}{c}\text { Total dose, } \\
\mathrm{mg} / \mathrm{kg}\end{array}$} & \multicolumn{2}{|c|}{ Lysozyme, units / kg } & \multirow{2}{*}{ \% decrease } \\
\cline { 3 - 4 } & 150 & $4,39 \pm 0,21$ & $\begin{array}{c}3,53 \pm 0,19 \\
\mathrm{p}<0,05\end{array}$ & 19,6 \\
\hline Hydrazine sulfate, in / & 105 & $5,11 \pm 0,04$ & $\begin{array}{c}4,42 \pm 0,19 \\
\mathrm{p}<0,02\end{array}$ & 13,5 \\
\hline abdominal & 90 & $5,18 \pm 0,37$ & $\begin{array}{c}1,59 \pm 0,34 \\
\mathrm{p}<0,01\end{array}$ & 69,3 \\
\hline $\begin{array}{l}\text { Cyclophosphamide, } \\
\text { in / abdominal, series I }\end{array}$ & 90 & $3,40 \pm 0,49$ & $\begin{array}{c}2,26 \pm 0,31 \\
\mathrm{p}<0,05\end{array}$ & 33,5 \\
\hline $\begin{array}{l}\text { Cyclophosphamide, } \\
\text { in / abdominal, series II }\end{array}$ & 300 & $4,84 \pm 0,18$ & $\begin{array}{c}5,04 \pm 0,34 \\
\mathrm{p}>0,3\end{array}$ & $+4,1$ \\
\hline $\begin{array}{l}\text { Lincomycin with drinking } \\
\text { water }\end{array}$ & 0,40 & $5,25 \pm 0,24$ & $\begin{array}{c}4,50 \pm 0,26 \\
\mathrm{p}<0,05\end{array}$ & 14,3 \\
\hline LPS in / abdominal & 0,066 & $4,64 \pm 0,20$ & $\begin{array}{c}4,14 \pm 0,06 \\
\mathrm{p}<0,05\end{array}$ & 10,8 \\
\hline LPS, oral applications & & & & \\
\hline
\end{tabular}

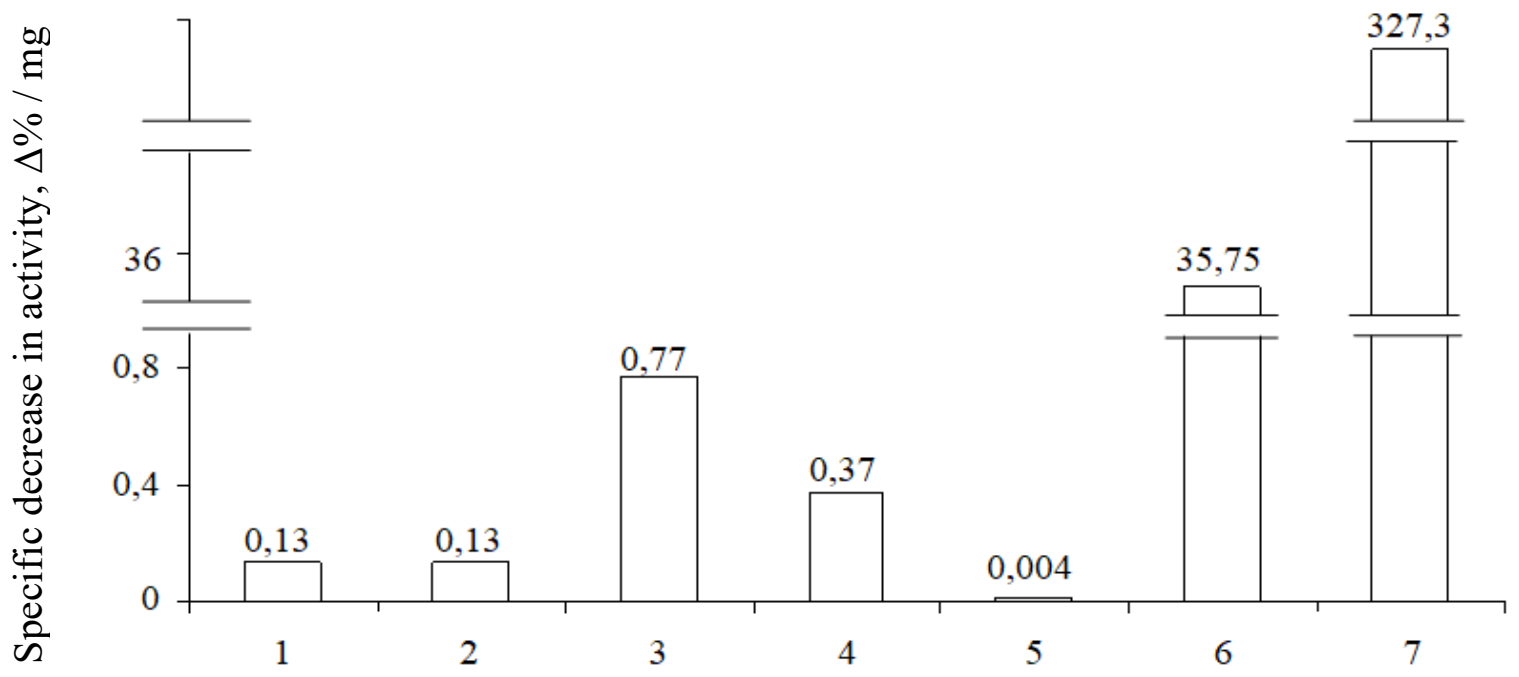

Fig. 1. Specific decrease in lysozyme activity $(\Delta \% / \mathrm{mg})$ in the kidneys of rats under the influence of various pathogens ( 1 - hydrazine sulfate, 2 - prednisolone,

3 - cyclophosphamide, 4 - cyclophosphamide, 5 - lincomycin, 6 - LPS in / abdominal, 7 - LPS applications on oral mucosa)

Our data on the extremely strong anti-lysozyme activity of LPS in the kidneys are consistent with the data obtained in the study of the effect of LPS on the activity of lysozyme in other organs $[7,12]$. 
Table 3 presents the results of the determination of urease activity in the kidneys. It is seen that in all cases there is a significant increase in urease activity, especially under the action of cyclophosphamide.

Table 3. Urease activity in the kidneys of rats under the action of various pathogens

\begin{tabular}{|l|c|c|c|c|}
\hline \multirow{2}{*}{ Pathogens } & Total dose, & \multicolumn{2}{|c|}{ Urease, $\mu$-cat / kg } & \multirow{2}{*}{$\%$ increase } \\
\cline { 3 - 4 } & $\mathrm{mg} / \mathrm{kg}$ & control & experiment & \\
\hline $\begin{array}{l}\text { Hydrazine sulfate, in / } \\
\text { abdominal }\end{array}$ & 150 & $0,39 \pm 0,08$ & $\begin{array}{c}0,91 \pm 0,10 \\
\mathrm{p}<0,01\end{array}$ & 141 \\
\hline Prednisolone, per os & 105 & $0,11 \pm 0,01$ & $\begin{array}{c}0,20 \pm 0,02 \\
\mathrm{p}<0,01\end{array}$ & 81,8 \\
\hline $\begin{array}{l}\text { Cyclophosphamide, } \\
\text { in / abdominal, series II }\end{array}$ & 90 & $0,03 \pm 0,01$ & $\begin{array}{c}0,18 \pm 0,06 \\
\mathrm{p}<0,05\end{array}$ & 500,4 \\
\hline $\begin{array}{l}\text { Lincomycin with drinking } \\
\text { water }\end{array}$ & 300 & $0,17 \pm 0,02$ & $\begin{array}{c}0,30 \pm 0,07 \\
\mathrm{p}>0,05\end{array}$ & 76,5 \\
\hline LPS in / abdominal & 0,40 & $0,28 \pm 0,06$ & $\begin{array}{c}0,57 \pm 0,10 \\
\mathrm{p}<0,05\end{array}$ & 103,6 \\
\hline LPS, oral applications & 0,066 & $0,56 \pm 0,03$ & $\begin{array}{c}0,72 \pm 0,17 \\
\mathrm{p}>0,05\end{array}$ & 28,6 \\
\hline
\end{tabular}

After recalculating the percentage increase in urease activity per $1 \mathrm{mg}$ of pathogen (Fig. 2), we see that the strongest pathogen was LPS. It exceeded 275 times the effect of hydrazine sulfate (for intraperitoneal administration) and 460 times (after oral administration).

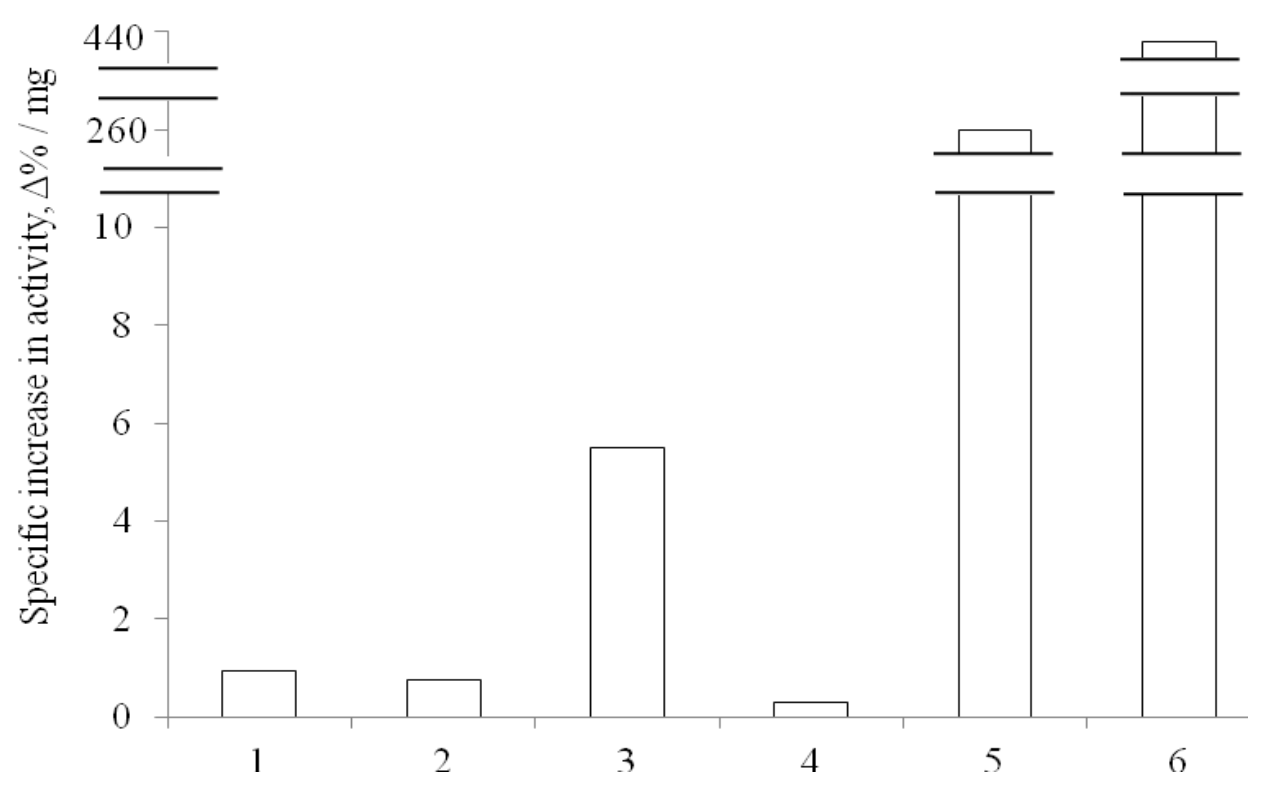

Fig. 2. Specific prourease activity in the kidneys of rats of various pathogens (1 - hydrazine sulfate, 2 - prednisolone, 3 - cyclophosphamide, 4 - lincomycin, 5 - LPS in / abdominal, 6 - LPS applications on oral mucosa) 
Calculated by the method of A.P. Levitsky degree of dysbiosis in the kidneys are presented in table 4, which shows that the highest degree of dysbiosis is observed in the kidneys of rats treated with the cytostatic cyclophosphamide. However, the proportion of dysbiosis was highest in rats treated with LPS: more than 328 times compared with rats treated with hydrazine sulfate, and after oral administration of LPS, it exceeded the rate of hydrazine by 1132 times (!).

Table 4. The degree of dysbiosis in the kidneys of rats under the action of various pathogens $($ control $=1.00 \pm 0.15)$

\begin{tabular}{|l|c|c|c|}
\hline \multicolumn{1}{|c|}{ Pathogens } & $\begin{array}{c}\text { Total dose, } \\
\mathrm{mg} / \mathrm{kg}\end{array}$ & $\begin{array}{c}\text { The degree of } \\
\text { dysbiosis }\end{array}$ & $\begin{array}{c}\text { The degree of } \\
\text { dysbiosis per 1 g of } \\
\text { pathogen }\end{array}$ \\
\hline $\begin{array}{l}\text { Hydrazine sulfate, in / } \\
\text { abdominal }\end{array}$ & 150 & $\begin{array}{c}2,91 \pm 0,30 \\
\mathrm{p}<0,01\end{array}$ & 19,4 \\
\hline Prednisolone, per os & 105 & $\begin{array}{c}2,12 \pm 0,23 \\
\mathrm{p}<0,05\end{array}$ & 20,2 \\
\hline $\begin{array}{l}\text { Cyclophosphamide, in / } \\
\text { abdominal }\end{array}$ & 30 & $\begin{array}{c}9,09 \pm 1,47 \\
\mathrm{p}<0,001\end{array}$ & 101,0 \\
\hline Lincomycin with drinking water & 0,40 & $\begin{array}{c}2,05 \pm 0,21 \\
\mathrm{p}<0,05\end{array}$ & 6,8 \\
\hline LPS, in / abdominal & 0,066 & $\begin{array}{c}2,55 \pm 0,26 \\
\mathrm{p}<0,01\end{array}$ & 6375 \\
$\mathrm{p}>0,05$ & & 21970 \\
\hline LPS, oral applications & & & \\
\hline
\end{tabular}

The data obtained indicate that stomatogenic endotoxinemia, which occurs after oral administration of LPS [1], has a stronger nephropathogenic effect than enterogenic, which is the result of intestinal dysbiosis. The reason for this difference in the nephropathogenic action of LPS is the antimicrobial function of the liver [13], which causes the protection of all organs, including the kidneys, from bacterial invasion and toxemia due to intestinal microbiota.

On this basis, the high nephroprotective effect of stomatropic therapy under conditions of various intoxications becomes clear.

Extremely high prodisbiotic activity of LPS causes a decrease in lysozyme activity and an increase in microbial contamination of the kidneys (as evidenced by a significant increase in urease activity) and gives some reason to hypothesize that nephropathogenic action of other non-microbial pathogens is realized through the interaction of the latter resulting in the formation of LPS. It is LPS and causes a decrease in lysozyme levels, increased urease levels 
and the degree of dysbiosis, which results in the development of inflammatory-dystrophic processes in the kidneys.

The use of antibiotics that reduce the number of bacteria, gives grounds for the use of antibiotic therapy for the treatment of kidney disease caused by intoxication.

\section{Conclusions}

1. Different pathogens (hydrazine, prednisolone, cyclophosphamide, lincomycin, LPS) cause the same reactions in the kidneys, namely a decrease in lysozyme activity, increased urease activity and the degree of dysbiosis.

2. In terms of specific nephropathogenic activity, the strongest was LPS, which exceeded the action of other pathogens by hundreds and even thousands of times.

3. On this basis, it is hypothesized that the nephropathogenic action of various pathogens may be due to their effect on bacteria, the lysis of which forms LPS.

4. Significantly greater nephropathogenic effect of LPS in stomatogenous endotoxinemia indicates the need for use in kidney disease stomatotropic therapy.

\section{REFERENCES}

1. Levitsky AP. Disbiotic syndrome: etiology, pathogenesis, clinic, prevention and treatment. Dentistry Bulletin. 2019; 10 (special issue): 14-20. (in Russian)

2. Dyatlov IA. Actual problems of medical microbiology. ZhMEI. 2013; 1: 88-93. (in Russian)

3. Shulpekova Y.O. The gut microbiome as a special organ. RZhGGK. 2014; 6: 82-88. (in Russian)

4. Levitsky AP, Makarenko OA, Denga OV [and others]. The experimental methods of restoration and estimation of the degree of dysbiosis in oral tissues. Dentistry Bulletin. 2010; 2: 22-23. (in Russian)

5. Levashov PA, Matolygina DA, Ovchinnikova ED [and others]. New sorbent based on covalently immobilized lysozyme to remove bacterial lipopolysaccharide (endotoxin) from biological fluids. Biochemistry. 2019; 84(1): 100-108. (in Russian)

6. Pustovoyt IP, Levitsky AP, Knava OE. Lysozyme and elastase activity in kidney tissue of immunodeficient rats under the action of lipopolysaccharide. Bulletin of Marine Medicine. 2013; 3(60): 65-67. (in Russian)

7. Levitsky AP, Ostafiichuk MA, Uspenskii OE [and others]. The influence of different pathogens on the lysozyme activity into tissues of rat oral cavity. Journal of Education, Health and Sport. 2017; 7(8): 1070-1081. 
8. Levitsky AP, Gozhenko AI, Stepan VT [and others]. Dysbiotic aspects of pathogenesis and antidysbiotic prophylactics of experimental nephropathy. Journal of Education, Health and Sport. 2017; 7(6): 1124-1136.

9. Levitsky AP. Lysozyme instead of antibiotics. Odessa, KP OGT, 2005: 74. (in Russian)

10. Gavrikova LM, Segen IT. Urease activity of oral liquid in patients with acute odontogenic infection of maxillo-facial part. Stomatology. 1996; The extra issue: 49-50. (in Russian)

11. Truhacheva NV. Mathematical Statistics in biomedical research using application package Statistica. Moskow, GJeOTAR-Media, 2012: 379. (in Russian)

12. Levitsky AP, Makarenko OA, Selivanskaya IA [and others]. Enzymatic methods for determination of oral dysbiosis for screening pro- and prebiotics: method guidelines. Kiev, GFC, 2007: 22. (in Russian)

13. Levitsky AP, Demyanenko SA, Tsiselskiy YuV. The antimicrobic function of liver. Odessa, KP OGT, 2011:141. (in Russian) 